Génét. Sél. Evol., 1984, 16 (1), 15-26

\title{
The geographical distribution of P-M hybrid dysgenesis in Drosophila melanogaster
}

\author{
D. ANXOLABEHẼRE, HU KAI *, D. NOUAUD, \\ G. PERIQUET ** and S. RONSSERAY \\ Laboratoire de Génétique des Populations, tour 42, Université Paris VII \\ 2, place Jussieu, F 75005 Paris \\ * Department of Biology, Northwestern University \\ Xian, People's Republic of China \\ ** Institut de Biocénotique expérimentale des Agrosystèmes, Université de Tours \\ Parc Grandmont, F 37200 Tours
}

\section{Summary}

In Drosophila melanogaster the syndrome of germline abnormalities generated in the $P-M$ system is caused by transposable elements known as the $P$ element family. The frequency of gonadal dysgenesis, $G D$ sterility characteristic of the $P \cdot M$ system, was estimated in 120 populations, collected in 1980-1983 from arround the world, in order to determine the present distribution of this system of hybrid dysgenesis. Marked geographical differences appear between these populations. In North America most of them possess individuals of the $P$ and the $Q$ type whereas the $M$ type is absent or present at only very low frequencies. A similar pattern has been found in central Africa, whereas the $P$ type is practically absent in North Africa, Europe and Asia. In these regions another pattern exists. In France the $Q$ type is very frequent and the $M$ type of low frequency, whereas $M$ becomes very common going to the east of Yugoslavia and Tunisia towards India, China and Japan. Hypotheses on the evolution of the $P-M$ system in natural populations polymorphic for the $P$ elements will be discussed.

Key words : Transposable elements, populations, polymorphism, evolution.

\section{Résumé}

Répartition géographique du système $\mathrm{P}-\mathrm{M}$ de dysgénésie des hybrides chez Drosophila melanogaster

Chez Drosophila melanogaster la dysgénésie des hybrides due aux éléments transposables de la famille $P$ est un syndrome d'anomalies génétiques incluant une stérilité thermodépendante et un fort taux de mutation. Afin de déterminer la distribution de ce système parmi les populations mondiales de drosophiles, un ensemble de 120 souches capturées entre 1980 et 1983 a été étudié pour ses potentialités de stérilité. En Amérique du Nord la plupart des populations possède des individus de type $P$ ou $Q$ tandis que le type $M$ est 
pratiquement absent. Une répartition similaire a été observée en Afrique centrale. Dans les autres régions (Afrique du Nord, Europe et Asie) une distribution différente est observée, dans laquelle le type $P$ est pratiquement absent. Le type $Q$ très fréquent en France se rencontre moins souvent vers l'est, tandis que le type $M$ assez rare en France se rencontre très fréquemment de la Yougoslavie au Japon. Les hypothèses de l'évolution du système $\boldsymbol{P}-\boldsymbol{M}$ dans des populations naturelles polymorphes pour les éléments $\boldsymbol{P}$ sont discutées.

Mots clés : Eléments transposables, populations, polymorphisme, évolution.

\section{Introduction}

The interactions of the $P-M$ system of hybrid dysgenesis, which are manifested in certain interstrain hybrids, result in a number of correlated aberrant genetic traits such as high frequencies of gonadal sterility ( $G D$ sterility) male recombination and mutation (KIDWELL et al., 1977). In the $P-M$ system three types of individuals, $P, Q$ and $M$, have been described on the basis of their cross effect properties. Hybrids between $P$ males and $M$ females show dysgenic traits that are reduced or absent in the reciprocal hybrids. $Q$ individuals do not exhibit $G D$ sterility in any cross combinations but produce mutation and male recombination in crosses with $M$ females. All $P$ and $Q$ strains so far examined carry 30-50 copies of the $P$ family of elements (BINGHAM et al., 1982 ; RUBIN et al., 1982). $Q$ individuals are thought to be a subset of the $P$ element family which appear to lack sterility potentiality while retaining mutator activity and other $P$ element functions (Engels, 1981 ; PériQuet et al., 1981; RUBin et al., 1982). Conversely, all-long-established laboratory $M$ strains examined (except one), completely lacked homology with the $P$ element family. $P$ elements are subject to destabilisation in the maternally derived cellular state of a $M$ strain ( $M$ cytotype) but are quasi-stable within a $P$ or a $Q$ cellular state ( $P$ cytotype) (ENGELS, 1979).

Although much previous research on transposable elements has been on their molecular properties, little is known about the population genetics of such sequences. The purpose of this report is to present the results of an extensive survey of actual $D$. melanogaster populations with respect to their dysgenic potential and to discuss hypotheses of the evolution of the $P-M$ system.

\section{Materials and methods}

120 strains derived from diverse localities around the world were determined with respect to their $G D$ sterility potential. Wherever possible each strain was derived from a large number (over 30) of recently collected (1980-1983) individuals. They were kept in standard laboratory conditions by mass culture of about 500 individuals and normally analysed during their first five generations following capture. For each strain two crosses were routinely made with the same $P$ and $M$ reference lines. Thirty individuals of the population under test were mass mated as follows :

Cross A : Canton-S $(M) q q \times$ ô ô under test.

Cross $A^{*}:$ $q q$ under test $\times$ ô $\hat{o}$ Harwich $(P)$. 
Dissection of $50 \mathrm{~F}_{1}$ females allowed an estimation of the frequency of dysgenic ovaries ( $G D$ sterility criterion). Cross A provided a measure of the activity of $P$ factors in males, and $P$ strains are not expected to produce more than trivial (5 p. 100) levels of $G D$ sterility in cross $\mathrm{A}^{*}$. Cross $\mathrm{A}^{*}$ distinguishes between $M$ cytotype ( $>5$ p. $100 G D$ sterility) and $P$ cytotype ( $<5$ p. $100 G D$ sterility). $Q$ strains are defined as those which produce less than 5 p. 100 of $G D$ sterility both in crosses $A$ and $\mathrm{A}^{*}$. Moreover, potentiality for intrastrain sterility was tested in each $M$ strain in order to avoid confusion between $G D$ sterility and maternally inherited sterility of character. Such as grandchildless (THIERRY-MEIG, 1976) or atrophie gonadique (PERIQUeT, 1980). The frequencies of $G D$ sterility were estimated using the method of KIDWELL et al. (1981).

\section{Results and discussion}

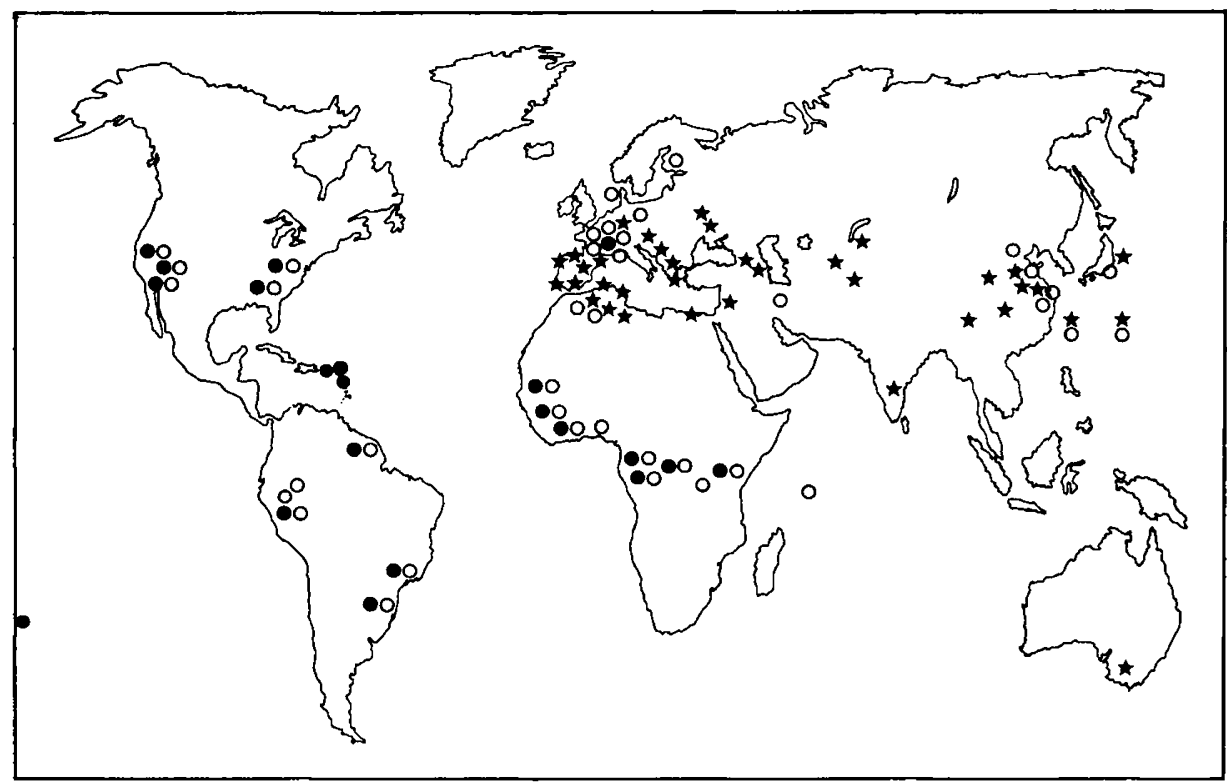

Fig. 1

Geographical distribution of world-wide collected strains according to their potential for the P-M system. $\mathrm{P}(\bullet), \mathrm{Q}(\mathrm{O})$ and $\mathrm{M}(*)$ strains.

Distribution du système $\mathrm{P}-\mathrm{M}$ de dysgénésie des hybrides. Souches $\mathrm{P}(\bullet), \mathrm{Q}(\odot)$ et $\mathrm{M}(*)$.

The data (fig. 1 and tabl. 1) show marked geographical differences in the present distribution of the $P-M$ system. In North America most of the strains show $P$ activity and have levels of induced $G D$ sterility which fluctuate around an average value of 15 p. 100. According to the technique used here (mass characterisation), this suggests that natural populations are polymorphic for $P$ and $Q$ types as has been previously demonstrated by ENGels \& PRESTON (1980) in a natural population from Madison 
and as can be shown here in the Concord iso-female lines. No $M$ strains have been identifield in the present study which agrees with the fact that $M$ strains have been found very rarely in modern U.S. populations (KIDwELL, 1983). In our study, $P$ strains have also been found in South America. The other main area where $P$ strains has been found is Central Africa from Senegal to Kenya. In these regions $M$ strains also appear rare and the observation of a relatively high level of intra sterility in one Cotonou strain does not allow its classification as an $M$ strain.

\section{TABLE 1}

Results of wild-type strains tested in the P-M system by their frequencies of GD sterility and intra-strain sterility.

Caractérisation des souches sauvages dans le système P-M, par leurs fréquences de stérilité GD et de stérilité intra-souche.

\begin{tabular}{|c|c|c|c|c|}
\hline \multirow{2}{*}{\multicolumn{2}{|c|}{ Strains, year of capture }} & \multicolumn{3}{|c|}{$\%$ of dysgenic activity } \\
\hline & & $P$ & $M$ & Intra-strain \\
\hline \multicolumn{2}{|l|}{ Americas } & & & \\
\hline \multicolumn{5}{|l|}{ U.S.A. } \\
\hline Winters $\ldots \ldots \ldots \ldots$ & 1982-A & 5.0 & 0.0 & 0.0 \\
\hline Winters $\ldots \ldots \ldots \ldots$ & 1982-B & 21.0 & 0.0 & 2.0 \\
\hline Winters $\ldots \ldots \ldots \ldots$ & $1982-\mathrm{C}$ & 12.0 & 0.0 & 0.0 \\
\hline El Rio $\ldots \ldots \ldots \ldots \ldots$ & 1982 & 12.0 & 0.0 & 一 \\
\hline Death Valley .......... & 1982 & 27.0 & 0.0 & 0.0 \\
\hline Raleigh $\ldots \ldots \ldots \ldots$ & 1982 & 20.0 & 0.0 & - \\
\hline Corscord ............ & $1982-1 *$ & 8.0 & 1.0 & 一 \\
\hline Concord ............ & $1982-2 *$ & 24.0 & 0.0 & 一 \\
\hline Corscord ............ & $1982-3^{*}$ & 9.0 & 0.0 & 一 \\
\hline Corscord $\ldots \ldots \ldots \ldots$ & $1982-4^{*}$ & 6.0 & 1.0 & - \\
\hline Concord $\ldots \ldots \ldots \ldots$ & $1982-5^{*}$ & 1.0 & 3.0 & - \\
\hline Concord $\ldots \ldots \ldots \ldots$ & 1982-6* & 2.0 & 2.0 & - \\
\hline Cossoord $\ldots \ldots \ldots \ldots$ & $1982-7 *$ & 3.0 & 3.0 & - \\
\hline Porto-Rico $\ldots \ldots \ldots \ldots$ & 1983 & 13.0 & 3.0 & 0.0 \\
\hline Saint-Thomas $\ldots \ldots \ldots$ & 1983 & 14.0 & 0.0 & 0.0 \\
\hline Guadeloupe...$\ldots \ldots \ldots$ & 1983 & 15.0 & 0.0 & 0.0 \\
\hline Guyane $\ldots \ldots \ldots \ldots$. & 1983 & 10.0 & 0.0 & 0.0 \\
\hline \multicolumn{5}{|l|}{ Brazil } \\
\hline Rio $\ldots \ldots \ldots \ldots \ldots$ & 1982 & 10.0 & 0.0 & 0.0 \\
\hline Porto Allegre..$\ldots \ldots$ & 1982 & 8.0 & 0.0 & 一 \\
\hline \multicolumn{5}{|l|}{ Peru } \\
\hline Iquitos & 1983 & 1.0 & 0.0 & 0.0 \\
\hline Huaraz $\ldots \ldots \ldots \ldots$ & 1983 & 9.0 & 0.0 & 0.0 \\
\hline Huaylas $\ldots . . . \ldots \ldots$ & 1983 & 3.0 & 1.0 & - \\
\hline
\end{tabular}

* Isofemale lines.

** Tested in 1982 . 
TABLE 1 (continued)

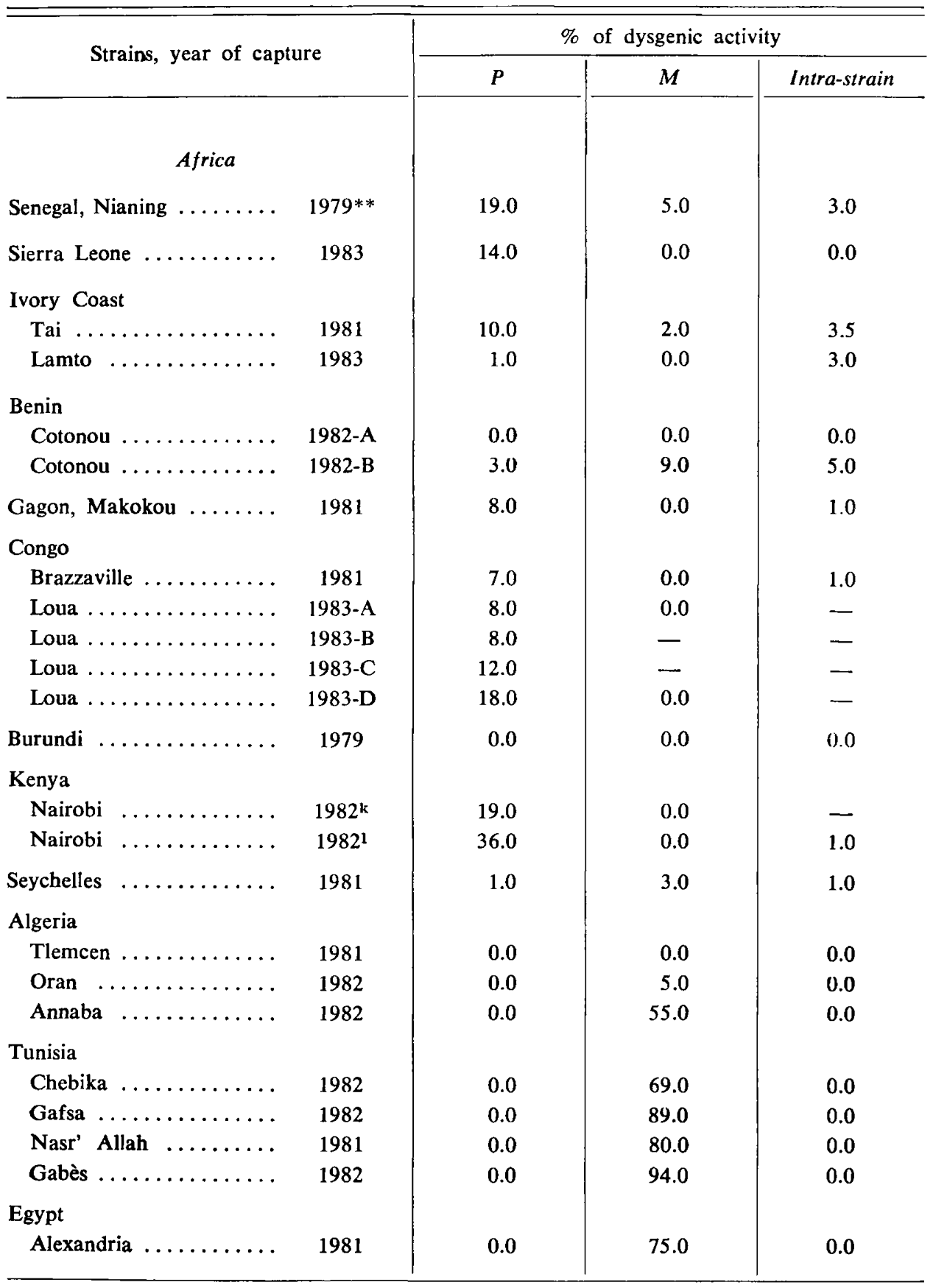

* Isofemale lines.

** Tested in 1982. 
TABle 1 (continued)

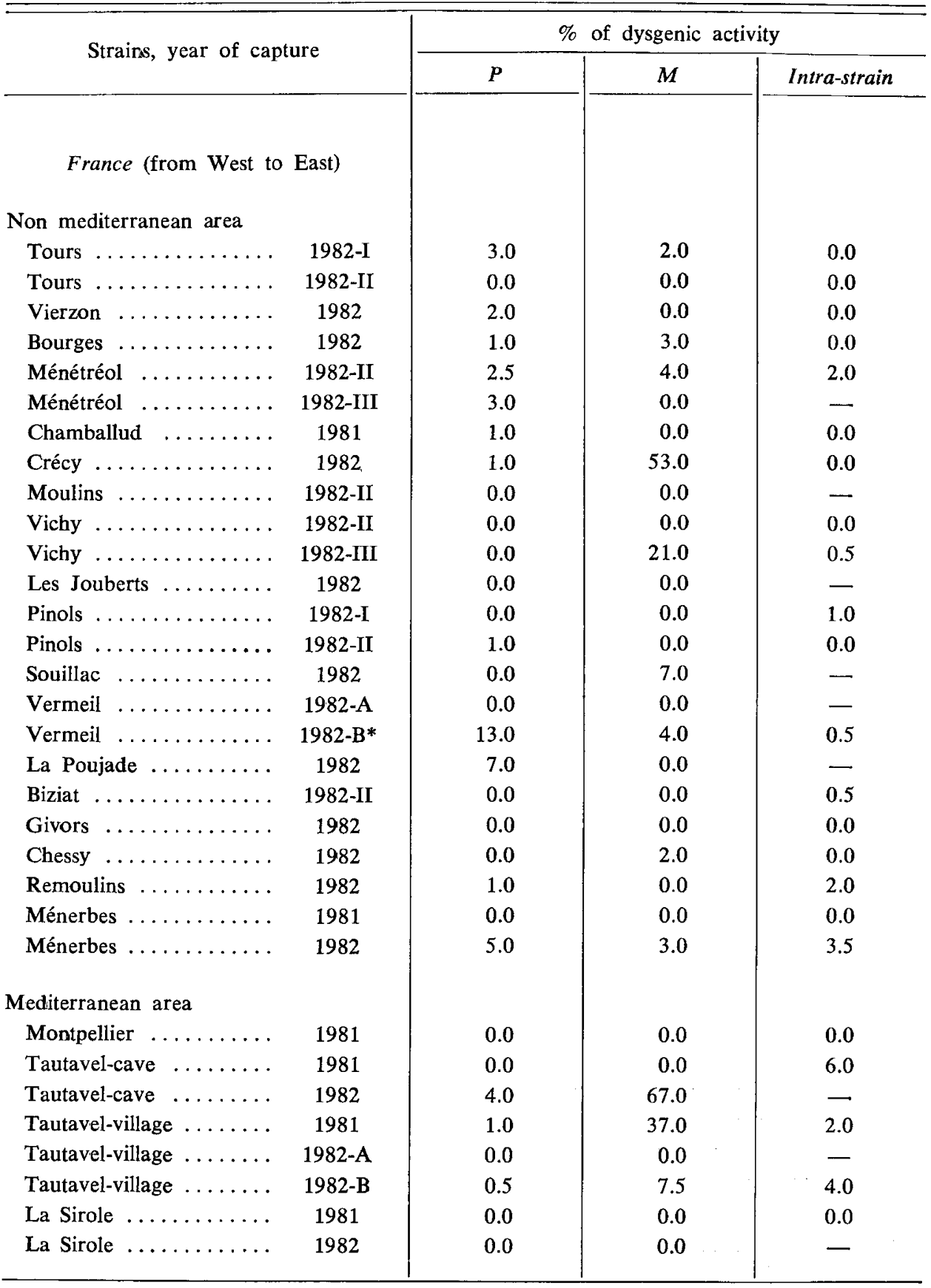

* Isofemale lines.

** Tested in 1982. 
TABLE 1 (continued)

\begin{tabular}{|c|c|c|c|c|}
\hline \multirow{2}{*}{\multicolumn{2}{|c|}{ Strains, year of capture }} & \multicolumn{3}{|c|}{$\%$ of dysgenic activity } \\
\hline & & $P$ & $M$ & Intra-strain \\
\hline \multicolumn{5}{|l|}{ Eur-Asia } \\
\hline Finland, Helsinki ....... & 1981 & 0.0 & 0.0 & 0.0 \\
\hline Denmark, Copenhaguen .. & $1980^{* * *}$ & 1.0 & 2.0 & - \\
\hline G.F.R., Tubingen $\ldots \ldots \ldots$ & 1982 & 0.0 & 1.0 & - \\
\hline Portugal, Algarv ....... & 1981 & 0.0 & 30.0 & 0.0 \\
\hline \multicolumn{5}{|l|}{ Spain } \\
\hline Gerona & 1980 & 0.0 & 38.0 & 3.0 \\
\hline Gerona $\ldots \ldots \ldots \ldots$ & 1982 & 0.0 & 56.0 & 一 \\
\hline Castropol .... & 1983 & 0.0 & 74.0 & 0.0 \\
\hline Aviles $\ldots \ldots \ldots \ldots \ldots$ & 1983 & 1.0 & 84.0 & 0.0 \\
\hline Viilaviciosa $\ldots \ldots \ldots$ & 1983 & 1.0 & 65.0 & 0.0 \\
\hline Sevilla $\ldots \ldots \ldots \ldots \ldots$ & 1983 & 0.0 & 19.0 & 0.0 \\
\hline \multicolumn{5}{|l|}{ Yugoslavia } \\
\hline Krsko .............. & 1982 & 0.0 & 86.0 & 0.0 \\
\hline Divcibare ........... & 1982 & 0.0 & 73.0 & 0.0 \\
\hline Slankamen .......... & 1982 & 0.0 & 75.0 & 0.0 \\
\hline \multicolumn{5}{|l|}{ Greece } \\
\hline Athens $\ldots \ldots \ldots \ldots \ldots$ & $1982^{e}$ & 0.0 & 78.0 & 4.0 \\
\hline Athens $\ldots \ldots \ldots \ldots$ & $1982^{\mathrm{k}}$ & 0.0 & 70.0 & 0.0 \\
\hline Mati $\ldots \ldots \ldots \ldots \ldots$ & $1982 *$ & 0.0 & 76.0 & 4.0 \\
\hline \multicolumn{5}{|l|}{ Israel } \\
\hline Jerusalem . . & 1982-A & 0.0 & 26.0 & 0.0 \\
\hline Jerusalem $\ldots \ldots \ldots \ldots$ & 1982-B & 0.0 & 22.0 & 0.0 \\
\hline \multicolumn{5}{|l|}{ U.S.S.R. } \\
\hline Gomel $\ldots \ldots \ldots \ldots \ldots$ & 1981 & 0.0 & 91.0 & 0.0 \\
\hline $\operatorname{Uman} \ldots \ldots \ldots \ldots$ & 1981 & 3.0 & 87.0 & 2.0 \\
\hline Ubinskaya $\ldots \ldots \ldots \ldots$ & $1982-2 *$ & 0.0 & 74.0 & 0.0 \\
\hline Ubinskaya $\ldots \ldots \ldots$. & $1982-6 *$ & 2.0 & 94.0 & 0.0 \\
\hline Tbilisi $\ldots \ldots \ldots \ldots$ & 1981 & 0.0 & 87.0 & 3.0 \\
\hline Tachkent $\ldots \ldots \ldots \ldots$ & 1981 & 1.0 & 91.0 & 0.0 \\
\hline Dusanbe $\ldots \ldots \ldots \ldots$ & 1982 & 0.0 & 96.0 & 6.0 \\
\hline Alma-Ata $\ldots \ldots \ldots$ & 1981 & 0.0 & 94.0 & 0.0 \\
\hline Iran, Teheran $\ldots \ldots \ldots \ldots$ & 1983 & 0.0 & 0.0 & 0.0 \\
\hline
\end{tabular}

* Isofemale lines.

** Tested in 1982. 
TABLE 1 (continued)

\begin{tabular}{|c|c|c|c|c|}
\hline \multirow{2}{*}{\multicolumn{2}{|c|}{ Strains, year of capture }} & \multicolumn{3}{|c|}{$\%$ of dysgenic activity } \\
\hline & & \multirow{2}{*}{$\begin{array}{c}P \\
0.0\end{array}$} & \multirow{2}{*}{$\begin{array}{c}M \\
52.0\end{array}$} & \multirow{2}{*}{$\begin{array}{c}\text { Intra-strain } \\
10\end{array}$} \\
\hline India, Mysore $\ldots \ldots \ldots$ & 1982 & & & \\
\hline \multicolumn{5}{|l|}{ China - Mainland } \\
\hline Kunming $\ldots \ldots$ & 1983 & 0.0 & 62.0 & - \\
\hline Xian...... & 1983 & 0.0 & 87.0 & $\ldots$ \\
\hline Changsha $\ldots \ldots \ldots \ldots$ & 1983 & 0.0 & 86.0 & - \\
\hline Beijing $\ldots \ldots \ldots \ldots$ & 1983 & 1.0 & 2.0 & - \\
\hline Jinan $\ldots \ldots \ldots \ldots$ & 1983 & 0.0 & 22.0 & - \\
\hline Nanjing $\ldots \ldots \ldots \ldots$ & 1983 & 0.0 & 43.0 & 一 \\
\hline$\ldots \ldots \ldots \ldots$ & 1983 & 0.0 & 3.0 & - \\
\hline Wuxi & 1983 & 0.0 & 18.0 & - \\
\hline Jinhua $\ldots \ldots \ldots \ldots \ldots$ & 1983 & 2.0 & 2.5 & 一 \\
\hline Zhenjiang $\ldots \ldots \ldots \ldots$ & 1983 & 0.0 & 0.0 & 一 \\
\hline \multicolumn{5}{|l|}{ China - Taiwan } \\
\hline Tong-pu $\ldots \ldots$ & 1981 & 2.0 & 0.0 & 3.0 \\
\hline Taichung $\ldots \ldots \ldots \ldots$ & 1981 & 0.0 & 28.0 & 0.0 \\
\hline \multicolumn{5}{|l|}{ Japan } \\
\hline Otsuki $\ldots \ldots \ldots \ldots \ldots$ & 1981-A & 0.0 & 2.0 & 0.0 \\
\hline Otsuki $\ldots \ldots \ldots \ldots \ldots$ & 1981-B & 0.0 & 5.0 & 0.0 \\
\hline Australia, Melbourne ..... & 1982 & 0.0 & 29.0 & 0.0 \\
\hline Tahiti & 1982 & 10.0 & 0.0 & 0.0 \\
\hline $\begin{aligned} * & \text { Isofemale lines. } \\
* * & \text { Tested in } 1982 .\end{aligned}$ & & & & \\
\hline
\end{tabular}

In North Africa, Europe and Asia the distribution patterns change dramatically, $P$ strains being almost absent and $M$ strains very common. In fact, a marked difference has been found between north western Europe, best characterised by the French populations, and the rest of Europe, the mediterranean and Asia. In France most current strains are $Q$ ones and the few observed $M$ strains are essentially mediterranean. Only two $P$ strains have been found, but in samples collected $4 \mathrm{kms}$ apart, and thus probably representing the same population. In all other regions from Yugoslavia to Japan, a majority of $M$ strains has been characterised, generally with a high level of $G D$ sterility. However some $Q$ strains have also been found and this observation suggests the existence of cytotype polymorphisms in these areas, as has been demonstrated in France, Tunisia and Japan (ANXOlABÉHÈre et al., 1982 a ; OHISHI et al., 1982). Nevertheless, we have to remember that if the patterns of all these regions appear devoid of $P$ strains, this situation may be due to the distribution of our sampling and that $\boldsymbol{P}$ sporadic types might exist as in France. Independently of the modern geographical variation KIDWELL (1983) has shown temporal trends in the distribution of strains. The frequency of $M$ strains is positively correlated with labo- 
ratory age and $P$ strains do not appear in samples taken before 1950, but then increase rapidly in frequency.

To explain these relationships ENGELS (1981) proposed the stochastic loss hypothesis in which the temporal trends result from the stochastic loss of $P$ elements when flies sampled from natural populations are maintained in the laboratory. However the presence of numerous $M$ strains in the wild supports the idea that an evolutionary process is responsible for their maintenance in natural populations. In her rapid invasion hypothesis, KIDWELL (1983) proposes that before about 1950 almost all natural populations were essentially of the $M$ type, the $P$ element family being absent or extremely rare. About 30 years ago, $P$ factors rapidely began to invade natural populations. The present distribution could then be explained by the complete invasion of most natural populations by the $P$ element family, but the structure and function of individual elements would be expected to vary widely due to internal deletion of element sequences leading to $Q$ or $M$ strains in different areas. However, from such a chiefly random process, different patches of homogeneity can be generated from a balance between migration and random drift (JoNES et al., 1981) and would be expected to lead to a very heterogeneous geographical distribution rather than the grouped distribution which we have found. Moreover, naturally occurring polymorphisms for the $\boldsymbol{P}$ factors (Engels \& Preston, 1980) and for the cytotype (AnXolaBÉHÈRE et al., 1982 a) are now known.

To include these data AnXolabéhère \& Periquet (1983) have proposed the recurrent phases hypothesis in which most natural populations are polymorphic for the $P$ family elements both in number and structure. $P$ elements with different functional properties are, they propose, commonly activated or inactivated by, for example, internal recombination between elements. The process of dispersion or regression of such elements would be under the control of balancing forces such as the rate of transposition, the occurrence of dysgenic hybrids, the ratio of the different types and fluctuations of their fitnesses in different environments (RONSSERAY, 1984) and would lead to successive and recurrent periods of invasion, stabilisation and regression, not necessarily synchronous over the whole world. During those periods, $P$ elements with sterility potentiality can be «inactivated 》 (e.g. replaced by $\boldsymbol{P}$ elements devoid of the sterility potentiality but not of their mutator activity), and populations polymorphic for the cytotypes (even with high level of $M$ cytotype as in Nasr'Allah) can exist. In such populations the reappearence of potential sterility can be produced, by the "reactivation》 or the reintroduction of active $P$ elements and a new invasion phase will start again. This evolutionary hypothesis is supported by the following observations : 1) some strong $M$ strains from North Africa, polymorphic for the cytotypes, have also revealed some structural homology with a cloned $\boldsymbol{P}$ element (ANXOlABÉHÈre et al., unpublished data) ; 2) in the U.S.A. the actual $\boldsymbol{P}$ factor activity of strains collected before 1970 is, average, considerably stronger than that of strains collected during the last decade (KIDWELL, 1983) ; 3) a similar but more advanced process seems to have occurred in France (ANXOLABÉHÈRE et al., $1982 \mathrm{~b}$ ) where the current predominance of wild $Q$ strains follows a previous period (1963-1973) in which $P$ and $M$ strains would have been more frequent; 4) the occurrence of periods of high mutability in natural populations of North America, Europe and Asia (GolubovsKY, 1980; BERG, 1982); and 5) the world-wide distribution patterns described here, which are better explained by deterministic rather than only stochastic factors. 


\section{Acknowledgements}

We are grateful to the following workers who sent us wild caught material : F.J. Ayala, E. Bahn, Y.A. Boussy, J. and M. Bouletreau, Y. Carton, J. David, R. Falk, Fei-J AnN Lin, A. Fleuriet, M.D. Golubovsky, H.N. Gopalan, J.M. GouX, M.M. Green, W.E. Kalisch, S.N. Karanja, L. Krimbas, H. Kurokawa, D. Lachaise, D. Marinkovic, M. Matechca, C. Monchamp-Moreau, L. Pilares Guevara, N. Plus, G. Ribo Monclus, J. Rouault, C. Tastemain, L. Tsacas, J. Vouidibio. This work was supported by grants ERA 406, LA 340 and GRECO 44 from the C.N.R.S. and the Mission de la Recherche.

\section{References}

Anxolabéhère D., Periquet G., 1983. Système $P$ - $M$ de dysgénésie des hybrides, polymorphisme génétique et évolution des populations de Drosophila melanogaster. Génét. Sél. Evol., 15, 31-44.

Anxolabéhère D., Nouaud D., Periquet G., 1982 a. Cytotype polymorphism of the $P-M$ system in two wild populations of Drosophila melanogaster. Proc. Natl. Acad. Sci. USA, 79, 7801-7803.

Anxolabéhère D., Nouaud D., Periquet G., 1982 b. Etude de la variabilité du svstème $P-M$ de dysgénésie des hybrides entre populations de Drosophila melanogaster. C.R. Acad. Sci. Paris, 294, 913-918.

BERg R.L., 1982. Mutability changes in Drosophila melanogaster populations of Europe, Asia, and North America and probable mutability changes in human populations of the U.S.S.R. Jap. J. Genet., 57, 171-183.

Bingham P.M., Kidwell M.G., Rubin G.M., 1982. The molecular basis of $P$ - $M$ hybrid dysgenesis : the role of the $P$ element, a P-strainspecific transposon family. Cell, 29, 995-1004.

ENGELS W.R., 1979. Hybrid dysgenesis in Drosophila melanogaster : rules of inheritance of female sterility. Genet. Res. Camb., 33, 219-236.

ENGELs W.R., 1981. Hybrid dysgenesis and the stochastic loss hypothesis. Cold Spring Harbor Symp. Quant. Biol., 45, 561-565.

Engels W.R., Preston C.R., 1980. Components of hybrid dysgenesis in a wild population of Drosophila melanogaster. Genetics, 95, 111-128.

Golubovsky M.D., 1980. Mutational process and microevolution. Genetica, 52-53, 139-149.

Jones J.S., Bryant S.H., Lewontin R.C., Moore J.A., Prout T., 1981. Gene flow and the geographical distribution of a molecular polymorphism in Drosophila pseudoobscura. Genetics, 98, 157-170.

KidWell M.G., 1983. Evolution of hybrid dysgenesis determinants in Drosophila melanogaster. Proc. Natl. Acad. Sci. USA, 80, 1655-1659.

KIDWell M.G., Kidwell J.F., Sved J.A., 1977. Hybrid dysgenesis in Drosophila melanogaster : a syndrome of aberrant traits including mutation, sterility and male recombination. Genetics, 86, 813-833.

KIDWell M.G., Novy J.B., FeEley S.M., 1981. Rapid unidirectional change of hybrid dysgenesis potential in Drosophila. J. Hered., 72, 32-38.

OHishi K., TaKanashi E., Ishiwa Chigusa S., 1982. Hybrid dysgenesis in natural populations of Drosophila melanogaster in Japan. I. - Complete absence of the $P$ factor in an island population. Jap. J. Genet., 57, 423-428.

Periquet G., 1980. "Atrophie gonadique » character and hybrid dysgenesis in Drosophila melanogaster. Biol. Cell., 39, 7-12. 
Periquet G., Green M., Anxolabéhère D., 1981. Corrélation entre activité mutagène et dysgénésie des gonades dans une souche de Drosophila melanogaster. Biol. Cell., 42, $181-184$.

RONSERAY S., 1984. Influence de la température sur le déterminisme cytotypique et sur l'évolution du système P-M chez Drosophila melanogaster. Thèse (Doctorat de spécialité), Université Paris 7.

Rubin G.M., Kidwell M.G., Bingham P.M., 1982. The molecular basis of $P$-M hybrid dysgenesis : the nature of induced mutations. Cell, 29, 987-994.

THIERRY-MiEg D., 1976. Study of a temperature-sensitive mutant Grandchildlesslike in Drosophila melanogaster. J. Microsc. Biol. Cell., 25, 1-6. 